\title{
Two New Publications by Norshahril Saat
}

\author{
Moch Nur Ichwan \\ Sunan Kalijaga State Islamic University \\ mochnurichwan@gmail.com
}

Norshahril Saat, The State, Ulama and Islam in Malaysia and Indonesia. Amsterdam: Amsterdam University Press, 2018, 254 Pp. ISBN 9789462982932, price: EUR 99.00 (hardback).

Norshahril Saat (ed), Islam in Southeast Asia: Negotiating Modernity. Singapore, ISEAS-Yusof Ishak Institute, 2018, xii + $25^{2}$ pp. IS BN 9789814786997 , price: USD 29.90 (softcover).

International studies of Islam and Muslim societies have long been dominated by Arab-centric perspectives. This is so not only in the sense that the Arabic countries are seen as the center of the Islamic world, but also that Islam in the Arab world is seen as the "pure" Islam, whereas Islam in the peripheral regions is considered impure and therefore less Islamic. However, the last two decades have seen a growing interest in international studies on Islam in the periphery, including Southeast Asia. While in the 199os most authors of Southeast Asian Islam were outsiders or Western and non-Muslim Asian scholars, many native Muslim scholars of Southeast Asia have since the 2ooos engaged in writing about their own history, culture, politics, and society. Norshahril Saat's two books here under review, The State, Ulama and Islam in Malaysia and Indonesia (hereafter, SUI) and Islam in Southeast Asia: Negotiating Modernity (hereafter, ISA) represent this trend.

SUI is Saat's monograph stems from his $\mathrm{PhD}$ at Australian National University (ANU). ISA is a collective volume he edited as part of the ISEAS-Yusof Ishak Institute's workshop on "Islamic Development in Southeast Asia" held in 2015, which was updated to include some further developments up to 2018. su focuses on the official Islamic scholars (ulama) in Malaysia and Indonesia, while ISA focuses on the issue of Middle Eastern influence and regional struggles with modernity in Malaysia, Indonesia, and Singapore.

Although the first book deals with the official ulama, and the second with much more diverse issues, both books share a similar concern: the issue of 
religious authority in Southeast Asia. The difference is that the former deals with traditional, conventional religious authority, while the latter deals with contested, decentralized, and fragmented religious authority in the wake of democratization and other local political processes.

In suI, Norshahril Saat comparatively analyzes the role of "official ulama" institutions in Indonesia and Malaysia under the authoritarian regimes of Suharto (1966-1998) and Mahathir Muhammad (1981-2003) respectively. He studies particularly Indonesia's Council of Ulama (MUI) and JKF-M KI (National Fatwa Committee), as well as Malaysia's Institute for Islamic Understanding (IKIM) and the Department of Islamic Development Malaysia (JAKIM). In the first three chapters, he deals with the theoretical framework used, historical and "glocal" factors facilitating the rise of Islamic resurgence, and the roots of state cooptation of the ulama in both countries. In chapters 4 and 5 , he discusses MUI and JKF-MKI as well as JAKIM and IKIM respectively. The conclusion (Chapter Six) focuses on the future of official ulama and state capture.

Unlike previous studies on official ulama, which emphasized the state's cooptation of these official ulama and undermined the former's ability to influence the latter, Norshahril has shown that despite processes of co-optation, both Indonesian and Malaysian official ulama have successfully "captured" the state. He introduces the concept of "capture", developed in the field of political economy, to explain the ways societal actors capitalize on state co-optation. $\mathrm{He}$ shows that both Indonesian and Malaysian official ulama have not only been co-opted by the state, but also captured some aspects of the state by influencing its policies, laws, and distribution of resources, especially those pertaining to Islam, such as issuing fatwa, halal certification, shariah economics, and Islamic tourism (pp. 29, 216-7).

Despite the similarities, there are also some significant differences between Indonesia and Malaysia. Suharto's institutionalization of ulama was superficial if not symbolic, whereas Mahathir's were more substantive (pp. 106-126), for instance. This has had some important consequences. Indonesian ulama are preoccupied with having their authority recognized, whereas Malaysian ulama are able to consolidate their power due to the existence of the laws and regulations protecting their position. Because of this, Indonesian ulama base their power more on Muslim conservatism than on state protection, while Malaysian ulama can act independently of societal demands.

ISA, the second book, discusses the political, cultural, social, and legal aspects of contemporary Islam in two Muslim-majority Southeast Asian countries (Indonesia and Malaysia), and Singapore, in which Muslims are a minority. It contains eight chapters, excluding editor's preface and introduction, written 
by scholars and activists from Singapore, Malaysia, and Indonesia about Islam in their respective countries. The book is divided into three sections: I on Malaysia (three chapters), II on Indonesia (four chapters), and III on Singapore (one chapter).

The basic argument developed in this book, as presented in the Introduction (Chapter One), is that "the Middle East influence [sic!] is more nuanced than what scholars think: while the negative impact on changing the attitude of Malay-Muslim [sic!] in the Nusantara [Southeast Asia] is felt, there are also positive influence [sic!] as well. On the other hand, there are also intra-regional dynamics that analysts have ignored." (p. 7). Indeed, unlike other current books on Islamism, ISA deliberately focuses on these "positive influence" and "intraregional dynamics" and puts aside the developments of Islamist radicalism. It presents the "other", moderate face of Islam, which is seen as a result of a negotiation between Islam and modernity.

The above argument is neatly shown in most chapters. In Section I on Malaysia, Wan Saiful Wan Jan argues that there is not only conservative Islamism, but also progressive Islamism (Chapter Two). The author refers to the Amanah Party, a party splintered from the All-Malaysian Islamic Party (PAS). The Amanah Party members were not satisfied with the conservative orientation of the PAs. In Chapter Two, Norshahril Saat argues that exclusivism is not only displayed by Salafi-Wahhabi legal experts (mufti), as is commonly argued, but also by Shafici and Sufi-oriented muftis. In some cases, the former even showed more progressive inclinations on "many issues not concerning religious rituals" than the latter. In general, he argues that "an exclusivist is exclusivist, regardless of whether he is a Wahhabi/Salafi, Shia, Sufi, Sunni or a self-declared liberal" (p. 56).

Unlike Norshahril, Mohd Faizal Musa in Chapter Four traces the significant role of Al-Madinah International University (MEDIU) in Selangor in disseminating Salafi-Wahhabist ideology not only in Malaysia but also in Southeast Asia more generally by applying a forensic theological approach. Although he does not suggest that the Salafi-Wahhabi ideology leads to terrorism, he suggests that "Wahhabism is an obvious threat and much prudence is needed in handling this movement" (p. 79).

The situation in Indonesia is discussed in Section II. The influence of the Middle East is discussed by Yon Machmudi and Azhar Ibrahim in Chapters Five and Six respectively. Mahmudi analyses the influence of a number of movements - Shia, Ikhwanul Muslimin, Hizbut Tahrir, Salafi, and Hizmet -in the formation from 1970s-2010s of the so-called "Campus Islam". Interrogating how these movements responded to the Arab Spring, he argues that the discourse has been influenced by the way their parent movements in the Middle 
East. These dynamics have triggered more fragmentation in the already fragmented Muslim communities in Indonesia.

Azhar Ibrahim analyses the transmission of Middle Eastern Islamic thought to Indonesia through translation. He analyses both "fundamentalist" (his own term) and progressive Islamic works. While he mentions fundamentalism only in terms of a movement, he discusses progressivism in terms of individual thinkers. Conversely, he mentions such Middle East movements as IkhwanulMuslimin, Hizbut Tahrir, and Salafism without mentioning individual fundamentalist thinkers. Among the more than 40 progressive Middle Eastern thinkers, we find Hassan Hanafi, Mohammed Arkoun, Abed al-Jabiri, and Nasr Abu Zayd, yet no progressive movement. The author observes that the translation of both fundamentalist and progressive Islamic works has enriched Indonesian Islamic thought.

Ahmad Najib Burhani and Najib Kailani focus on local dynamics. Burhani delves into the so-called Defending Islam Action (Aksi Bela Islam), a series of Muslim mass rallies in 2016-2017 emerging in protest against Jakarta's former governor Basuki Tjahaya Purnama (Ahok), who had been charged with committing religious defamation (Chapter Seven). Burhani argues that this phenomenon was a critical event, reflecting the fragmentation and contestation of religious authority in Indonesia.

In Chapter Eight, Najib Kailani discusses the issue of capitalist-driven religious markets by analyzing the phenomenon of "preachers-cum-trainers" as promoters of the so-called "market Islam". He studies Imaduddin Abdurrahim, who combines Islamic theology (tauhid) with Western management theory; Toto Tasmara, who developed "Islamic work ethics"; Ary Ginanjar and Muhammad Syafii Antonio, who developed "Islamic corporate management theory"; and Abdullah Gymnastiar and Yusuf Mansur, who developed the idea of "Islamic prosperity". Kailani has tried to move beyond the conservativeprogressive dichotomy and Middle Eastern influence, yet the above preacherscum-trainers are evidently conservative in terms of religious thought and keen to Islamize economic fields.

The last section, Chapter Nine, deals with Islam in Singapore. Noor Aisha Abdul Rahman discusses how religious elites in Singapore developed sharia revivalism, although they do not openly promote an Islamist discourse. They see modern and Islamic discourses in a dichotomous way, operating within the context of Singapore's minority-specific legal interpretation of Islam ( fikih), in which scenarios of harm, reality, capability, and proselytizing (dakwah) are carefully avoided.

Although Malaysia is mentioned before Indonesia in the title of sUI, Indonesia is mentioned before Malaysia throughout the book. The book's use of the 
term "official ulama" to designate the MUI is problematic. Unlike Malaysia's ulama institutions, the MUI is not part of the state; it is part of the Muslim society, although the government have evidently intervened in its establishment. The MUI is recognized as the representative of Indonesia's Muslim organizations, akin to the Communion of Indonesian Churches (PGI) for Protestantism, the Bishops' Conference of Indonesia (KWI) for Catholicism, the Indonesian Association of Hindu Dharma (PDHI) for Hinduism, the All-Indonesia Federation of Buddhist Organizations (Walubi) for Buddhism, and the Supreme Council of Confucian Religion in Indonesia (MATAKIN) for Confucianism. There are some typos in the book, such as BAYARNAS (for BASYARNAS, p. 142), Yayasan Dakwan (for Yayasan Dakwah, p. 77), Badan Standardisi (for Badan Standardisasi, p. 146), and Sahal Mahfuzd (for Sahal Mahfudz, p. 16o). Direktori Syariah Indonesia, the title of a book, is written inconsistently either as "syariah" (pp. 138, 231, 251) or "shariah" (pp. 137, 138, 139, 140).

ISA has tried to dismantle a strand of scholarship emphasizing the influence of the Middle East — the so-called Arabization — and its association with Islamic radicalism in Southeast Asia. Somewhat paradoxically, it simultaneously documents the rise of Salafism and conservatism in the last decades in the three countries under study, and their possibly strong impact in the future.

Nevertheless, these two books are valuable contributions to the field, representing how Southeast Asian Muslim scholars and activists write about their own religion in their own respective countries. Such studies are important amid the broad availability, if not dominance, of similar books and collective volumes written by non-Southeast Asian scholars. These two books have undeniably contributed to the study of contemporary developments of Islam and their dynamics in Southeast Asia; one of the most significant yet still somewhat neglected peripheries of the Islamic world. 